\title{
Govor vasi Topole
}

\author{
Mateja Jemec Tomazin
}

V prispevku je predstavljen govor vasi Topole, ki leži ob cesti Mengeš-Brnik. V njem se odražajo glasoslovne in oblikoslovne značilnosti tipičnega gorenjskega narečja. Po Ramovševi klasifikaciji spada topolska govorica v osrednji gorenjski govor, ki se govori v trikotniku Ljubljana-Kamnik-Kranj. Poleg glasovnega opisa so v razpravi predstavljeni tudi lokalno zelo razširjeni frazemi, temu pa sledi še topolsko-knjižnoslovenski slovarček.

Ključne besede: slovenska narečja, gorenjsko narečje slovenščine, narečni slovar

\section{The subdialect of the village of Topole (Slovenia)}

This article presents the subdialect of the village of Topole, located on the road from Mengeš to Brnik. It has the phonological and morphological characteristics of a typical Upper Carniolan dialect of Slovenian. According to Ramovš' classification, the Topole subdialect belongs to central Upper Carniolan, spoken in the Ljubljana-Kamnik-Kranj triangle. In addition to a phonological description, the article also presents phrasemes in very widespread use locally, followed by a Topole dialect-standard Slovenian glossary.

Key words: Slovenian dialects, Upper Carniolan dialect of Slovenian, dialect dictionary

0 Topolska govorica je v osnovi zelo podobna mengeški, o kateri je na kratko pisal Tine Logar (1996: 390-391). ${ }^{1}$ Značilnosti, ki jih je z nekajdnevnim raziskovanjem odkril in dokumentiral Logar, se v zadnjem času nekoliko spreminjajo, kar je posledica večje mobilnosti tako mlajših kot starejših prebivalcev, nekatere značilnosti topolske govorice pa ostajajo nespremenjene.

Mengeška občina (tako kot sosednja domžalska) leži na vzhodni meji značilne gorenjščine, na drugi strani Domžal v smeri proti moravški dolini pa se ta prelomi in dobi posebno obliko, ki je sicer še gorenjska, vendar precej daleč od tistega, kar pojmujemo za značilno gorenjščino (pojavijo se diftongi in izgubijo se značilna tonemska nasprotja) - gre za t. i. vzhodnogorenjsko podnarečje (prim. Logar 1996: 390). Po Ramovševi klasifikaciji spada topolska govorica v osrednji gorenjski govor, ki se govori v trikotniku Ljubljana-Kamnik-Kranj.

1 Članek je razširjeno poglavje Topolska govorica, ki je izšlo v avtoričini monografiji Topole nekdaj in danes (Jemec Tomazin 2008). 
Topôle so od Mengša oddaljene dobra dva kilometra in ležijo na nadmorski višini 328 metrov, in sicer pod obronki Debelega vrha ali Slevskega hriba (445 m) na levem bregu Pšate. Z Mengšem jih povezuje asfaltirana cesta. Vas z okoli 50 hišami se razteza ob križišču cest Mengeš-Suhadole in Križ-Skaručna. ${ }^{3}$ Topole so tako ena izmed redkih slovenskih vasi, ki imajo tloris poti v obliki križa (prim. Jagodic 1958: 8). Leta 1893 je požar uničil skoraj polovico vasi, vendar v požaru ni nihče umrl. Večina vaških hiš je bila v tistem času še lesenih, zato je bila škoda tolikšna, da so pomoč zanjo zbirali celo v Ljubljani (prim. Stražar 1980: 458). Danes je kot kulturni spomenik zaščitena le hiša št. 28 , po domače Udámova, vendar tudi ta domačija v zadnjih letih propada. Še pred dvajsetimi leti je bila glavna dejavnost v vasi kmetijstvo; danes je večina kmetij opuščenih, gospodarijo le še na posameznih. Nekatere kmetije še kažejo značilne elemente nekdanje podeželske arhitekture (npr. Aleškova, Udamova, Janščeva domačija), vendar je žal večina starih kmečkih hiš in poslopij predelanih ali popolnoma na novo pozidanih (tako npr. Vrbčeva, Hrinova, Testenova, Zajčeva domačija).

Izrazito vaško središče je gasilski dom in večina vaščanov je tudi članov gasilskega društva. Danes se vsi mladi po končani osnovni šoli odločijo za srednjo šolo, nekateri tudi za študij na fakulteti; največkrat si za kraj šolanja izberejo Ljubljano, Domžale in Kamnik, nekateri tudi Kranj.

\subsection{Zgodovina vasi}

Leta 2000 so Topole praznovale 750 . obletnico prve omembe. Oglejski patriarh Bertold Andeški je 13. avgusta 1250 izdal potrdilno listino, s katero je stiškemu samostanu potrdil njegovo posest, med drugim tudi štiri kmetije v Topolah. Posamezne najdbe kažejo, da je bilo področje naseljeno že v času Rimljanov. ${ }^{4} \mathrm{~V}$ preteklosti je vas spadala pod več gospostev: razmeroma malo kmetij je bilo v lasti mengeških gospodov, ${ }^{5}$ nekaj kmetij pa je bilo vse do jožefinske reforme last stiških cistercijanov in bistriških kartuzijanov. ${ }^{6}$ Skozi Topole je pred izgradnjo asfaltirane in širše povezovalne ceste sredi polja tekla glavna povezava od Mengša proti Kranju.

2 Prebivalci Topol so Topolci [topó:úci] in Topolke [topó:unke].

3 V Topolah se asfaltirana pot spremeni v gozdno in se priključi medkrajevni cesti Mengeš-Koseze, vendar gre za nekdanjo glavno povezavo s kamniškega (štajerskega) konca proti Skaručni in naprej proti Ljubljani.

4 Več v Jemec Tomazin 2008: 39-54.

5 V Mengšu se je zvrstilo kar nekaj plemiških rodbin, med drugim Gallenberški, Hohenwarti, v 14. in 15. stoletju pa tudi rodbina Mengeških. Gallenberški in Hohenwarti so bili tudi lastniki posesti v okolici Topol - mekinjskega samostana, kriškega gradu, gradu v Volčjem Potoku ...

6 Prim. Jemec 2000: 28-30. 


\subsection{Izvor imena}

Pisni viri na več mestih $^{7}$ poudarjajo, da je vas dobila ime po drevesni vrsti - topolu. Kraji, ki so poimenovani po drevesnih vrstah, so stari. ${ }^{8}$ Zanimivo je, da danes v okolici vasi ne raste mnogo topolov. Nastanek besede topol etimološko še ni zadovoljivo pojasnjen. ${ }^{9}$ Verjetno je izposojena iz vzhodnolatinskega *papulus, iz česar je izposojeno tudi starovisokonemško papil, nemško Pappel 'topol'. Druga možnost je domneva o sorodstvu med latinsko in slovansko besedo. Prvotni pomen besede naj bi bil 'štrleč' in jo povezujejo s slovenskim glagolom tepsti. Etimološka razlaga, ki naj bi ime kraja povezovala z imenom za prebivalce (*popolus), ni dokazana.

Pojavlja se tudi tretja, ljudskoetimološka razlaga, temelječa na zapisu, ki se je pred drugo svetovno vojno pojavljal na posameznih zemljevidih ali listinah, torej Topolje. Izgubo $j \mathrm{v}$ zapisu so okoliški pisci krajevnih kronik pojasnjevali z gorenjskim narečjem, češ da naj bi mehki lj otrdel, saj vas stoji na polju, torej naj bi šlo etimološko za *to-polje. ${ }^{10}$

\section{Fonemski sestav topolske govorice ${ }^{11}$}

\section{$2.1 \quad$ Vokalizem}

Za topolski govor so značilni dolgi monoftongični samoglasniki ( $i_{i}, u_{i}$, ẹi, $o_{i}$, e $e_{i}$, $o:, a^{\prime}$ ) in razlikovanje med akutom in cirkumfleksom na dolgih naglašenih samoglasnikih. Naglasno mesto je tako kot v knjižnem jeziku svobodno, vendar pa se ohranja značilno gorenjsko končniško naglaševanje in končniški naglasni tip (unhká: ali $\left.u h^{\prime} k a\right)$.

2.1.1 Dolgi naglašeni samoglasniki so takšni kot v knjižnem jeziku. Vsak od njih je lahko ali akutiran ali cirkumflektiran. /ar/ je en fonem in zveza dveh fonemov.

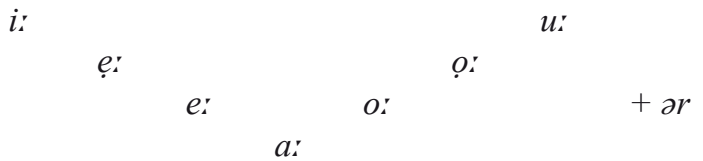

Dolgi $i:$ najdemo npr. v besedah šíbica, gradbí:še, sodíše, čpí:na 'črepinja', míslam, žvína, /i:/ pa nastopa tudi v sposojenkah iz drugih jezikov, zlasti iz bavarščine ${ }^{12}$ (dìla, cìmor, vì:ža).

7 Prim. Stražar 1980; 1993; KLS 1971.

8 Prim. Stražar 1993: 73.

9 Prim. Snoj 1997 in Bezlaj 2005, geslo topol, ter Snoj 2009, geslo Topol.

${ }^{10}$ Ta razlaga je najmanj verjetna, saj se tudi v starih listinah ne pojavlja mehki $l$, kar bi bil dokaz za takšen jezikovni razvoj, zato pa zanimivo Milko Kos v svojem gradivu za historično topografijo Slovenije (1975: 639) navaja obliko Topolje pri Mengšu, ki se po drugi svetovni vojni sploh ni pojavljala.

${ }^{11}$ Način opisa govora povzemam po Škofic 2001 in Logar 1996: 173-179.

${ }_{12}$ Povzeto po narečnem gradivu iz Repenj (Logar 1996: 174). 
Dolgi $u$, ki se je razvil iz psl. $u$, je v besedah, kot so kubú:k 'klobuk', klú:ka, lú:kna, čeprav se je /u:/ v Topolah razvil tudi iz skupine unu: < ưu;, tu', pojavlja pa se

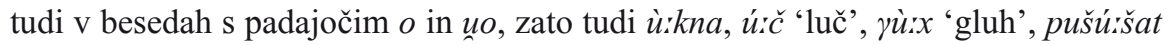
'poslušati', puù̀bwat 'pooblati', u dùrran 'v dvorani' ...

Ozka dolga ẹ: in $o$ : se govorita tako kot v knjižnem jeziku (npr. v besedah lẹ́:t, pẹ̀st, zvẹ́:zda, nẹ́su; mẹ̀ssac, lẹ́:tam; mọ̀sst, kọ̀sst, kọ́:ža, xọ́:dam). Ta dva samoglasnika sta se v položaju za $j$ ali $w / u$ skrajšala, doživela redukcijo in prešla v a ('jaza 'jeza', zob'ja 'zobje', 'jani 'jenjaj'. Redukcija za $j$ je še vedno močna, redukcija za $w / u$ (vôs $>$ 'ues, 'wəka 'loka', 'waitra 'lojtra' - pa se pojavlja samo še v posameznih besedah.

Tudi dolga $e:$ in $o:$ se pojavljata tako kot $\mathrm{v}$ knjižnem jeziku, največkrat ju najdemo v predzadnjih zlogih; če pa se je končni samoglasnik reduciral, pa tudi v zadnjih ali edinih (npr. mé:tla, cé:sar, mé:de < 'mesti', čéru, žé:u, óssu/vó:su, órru).

Topolski / $a$ : zastopa $^{13}$ psl. $a$ in $a<b, b$ v dolgih zlogih, nastopa pa tudi $\mathrm{v}$ mnogih sposojenkah (svá:ma, xrá:st, ná:ša, má:ln 'mlin', tá:bərx).

ar zastopa splošnoslovenski zlogotvorni $r \mathrm{v}$ dolgih zlogih (pàrst, vàrt, yàrda).

2.1.2 Kratki naglašeni samoglasniki so pod vplivom izrazite moderne vokalne redukcije in prehajajo $\mathrm{v} \partial$.

$\begin{array}{lll}i & & (u)>\partial \\ e & & o \\ & \partial & \\ & a & \end{array}$

Npr. v besedah št'rək 'vrv', 'məš 'mišs', 'kap 'kup', b'rat 'brat', ta'kət 'takrat'.

\subsubsection{Nenaglašeni samoglasniki}

Prednaglasni $e$-jevski glasovi so tako $\mathrm{v}$ topolščini kot mengeščini reducirani $\mathrm{v} a$ (npr. natopẹ́:r 'netopir', uad'mo 'vemo', uas'te 'veste', Magkšạa:na 'Mengšana', nadẹ́:la 'nedelja'), o-jevski glasovi pa so prešli v $u$ (t. i. o-jevsko ukanje, npr. kubú:k, kubá:sa), le ob $w$ je tak $o$ oslabel v polglasnik - zanj imamo torej enak rezultat kot za dolgi $o$ v enakem soglasniškem okolju (npr. zwəmì'wa 'zlomila').

Tudi kratki ter nenaglašeni pred- in ponaglasni $i$ in $u$ sta se reducirala $\mathrm{v}$ polglasnik (npr. marù: 'miru', xadì: 'hudi', səšé:mo 'sušimo', štadẹ̀rral 'študirali', jẹ́:sax 'kis', má:lan 'mlin'). Če izgovorljivost to omogoča, so ti glasovi tudi onemeli (žvì', sxì̀, sxọ̀r, xpì̀wa, aldjẹ́r).

$\mathrm{V}$ topolski govorici je polglasnik zaradi redukcije drugih kratkih samoglasnikov zelo pogost, se pa danes pod vplivom knjižnega jezika v nekaterih (doslej naštetih) položajih opušča in se na njegovem mestu ponovno govori polni glas. ${ }^{14}$

$\mathrm{V}$ polglasnik je oslabel tudi izglasni $-u \mathrm{v}$ končnici dajalnika in mestnika ednine moškega in srednjega spola (npr. brá:tə 'bratu', toda tudi brá:t), izglasni nenaglašeni $-i \mathrm{v}$ dajalniku in mestniku ednine ženskih samostalnikov pa je onemel

${ }^{13}$ Prim. gradivo za Repnje (Logar 1996: 174).

${ }^{14}$ To je odvisno predvsem od posamezne besede in ne od glasovnega okolja. 
(má:m 'mami', špẹ̀:l 'Špeli', té:t 'teti'), prav tako tudi izglasni - $i$ v imenovalniku množine moškega spola (stá:rš 'starši', utró:c 'otroci'). Pridevniška končnica -ov se je asimilirala v -u (já:nəzu pískar 'Janezov lonec/Janezova glava').

$\mathrm{V}$ ponaglasnih zaprtih zlogih se $i, u$ in $e$-jevski glasovi navadno spremenijo v ə (mìslam, trẹ: bəx, vá:rax). Glas o se v ponaglasnih zlogih navadno spremeni v $a$ (akanje) - stárrast, žá:wast, bístrast ('starost', 'žalost', 'bistrost'). V izglasnih zlogih pa $e$-jevski in $o$-jevski glasovi navadno ne spremenijo kakovosti, pač pa se je položajno $u$ reduciral prek a vo (gú:nmo/ zú:nmo fà:ntə 'tistemu fantu'). ${ }^{15}$

Topolska govorica se od mengeške razlikuje tudi po tem, da je oblika deležnika na - $l$ moškega spola nekaterih glagolov bolj asimilirana kot v Mengšu (npr. 'šu, par'šu namesto 'šou, por'šou < 'šel', 'prišel').

\subsection{Konzonantizem}

V soglasniškem sestavu je zelo zanimiv spirantizirani izgovor soglasnika $g$ (npr.

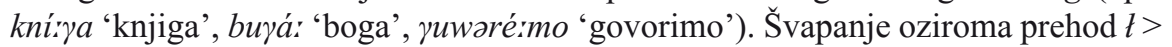
$w$ pred zadnjimi samoglasniki $a, o, u \mathrm{v}$ zadnjih letih izginja, vendar je pri nekaterih besedah skorajda dosledno ohranjeno/leksikalizirano (npr. dẹ́:wat 'delat', swá:ma

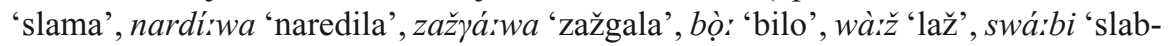
še', prẹ̀:kwar 'visoki fižol', ne pa tudi *twá:ka, ki ostaja tako kot v knjižni slovenščini tlá:ka). V svojilnih zaimkih svoj, tvoj je $v$ onemel (sọ́rj, tọ́:j). Pred vzglasnim $o$-jevskim samoglasnikom je pogost protetični w/u (npr. wókłan 'okno' - oblika 'ůzən pa izginja; wọ́:rə⿹k 'oreng - popolnoma, zelo', 'won 'on', wó:su 'osel').

Za topolsko govorico so značilne tudi olajšave soglasniških sklopov:

tk> xk (gwax'ka 'gladka', rẹ́xka 'redka')

$k t>x t$ (trá:xtor 'traktor', alè:xtrika 'elektrika')

$p t>(f t)>x t$ (droxtí:ne 'drobtine', vendar 'toč, ne $x^{\prime}$ tač 'ptič')

$p k>f k$ (redko, dosledno v besedi rọ́ffkat (iz)robkati '(iz)luščiti' kurú:zo tudi karú:zo in korú:zo)

$x t>f t$ (pošlìftan 'pošlihtano - urejeno') ${ }^{16}$

$p c>f c$ (kwò̀:fca 'klopca', xwà'fca 'hlapca') ${ }^{17}$

čk $>$ šk (má:ška 'mačka')

$\check{c} n>\check{s} n$ (svéršsnca 'svečnica')

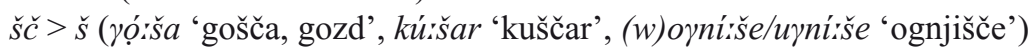

$p \check{s}>u \check{s}$ (ǔšeníca 'pšenica', lẹ:ǔ́s 'lepši')

$m n>$ un (wárkouna 'lakomna', pò̀unem 'pomnim')

$m n>m l$ (Ká:molk 'Kamnik')

15 Tine Logar (1996: 402) navaja, da se je ta oblika, ki je rezultat vpliva $m$ v dajalniku in mestniku ednine kazalnih zaimkov in pridevnikov, posplošila še v druge položaje. V Topolah ne poznamo siceršnje bolj razširjene gorenjske oblike gunmo fanto.

${ }^{16}$ Gre bolj za hiperkorekturo, ker se uporablja samo v posameznih besedah, ne pa dosledno.

17 Ta soglasniški pojav izginja. 
Redukcija nenaglašenih samoglasnikov skupaj s soglasniško asimilacijo po zvenečnosti lahko zelo spremeni besedo (npr. tìzza 'tistega', wá:mbər 'lambar - vedro').

Zanimiv pojav, ki se sicer opušča, je tudi analogični $l$ namesto $v$ (cẹ́rrkle 'cerkve', rwá:le 'glave', rokà:la 'rokavi').

Pogosto se pojavlja tudi sekundarni $j$ (pọ́:jstla, yrajšína).

Mehki ń je otrdel v $n$ (né:mo 'njemu', 'kon 'konj')

\section{Oblikoslovje}

$\mathrm{Na}$ oblikoslovni ravnini je izrazita dosledna maskulinizacija samostalnikov srednjega spola v ednini (npr. w'roč sọ̀nnce 'vroče sonce', dé:bu té:le 'debelo tele', mè:jxan já:jic 'majhno jajce', s'tər kulọ: 'staro kolo'), pri večini besed pa tudi feminizacija v množini (velìke ộkna, drubnẹ: já:jca). Zanimiva je tudi končnica - $a$ v množini nekaterih samostalnikov moškega spola (večé:ra 'večeri', ruká:la 'rokavi', jermẹ́na 'jermeni'). Končnica orodnika ednine in dajalnika množine moškega spola je -am (fá:ntam 'fantom').

Dvojina je ohranjena v pridevniški in zaimenski sklanjatvi in pri glagolskih oblikah, manj pa pri samostalnikih (bolj je ohranjena $\mathrm{v}$ imenovalniku in tožilniku), npr. (dva) drovẹ́:sa, stó:la, stəb'ra.

Pri stopnjevanju pridevnikov in prislovov se za tvorbo primernika in presežnika večinoma rabi priponsko obrazilo -ji (tudi tam, kjer je v knjižnem jeziku -ši), razlike so tudi zaradi samoglasniške redukcije in švapanja (bọ:l 'boljše', lọ̀zži/wọ̀:žil) wəžzi 'lažje', swá:bi 'slabše', stà:ri 'starejši', vẹ̀:č 'večji').

Opazna je raba člena ( $t a$ 'porve, ta s'tar).

\section{Besedje}

Leksemsko se topolska govorica ne razlikuje od ostale gorenjščine, uporablja se npr. veliko izposojenk iz nemščine (tá:lar 'krožnik', šàılca 'skodelica', pèrylozən 'likal-

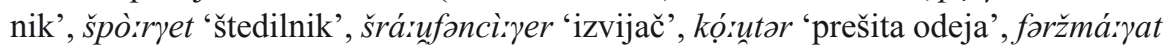
'zameriti se'). Vpliv angleščine in hrvaščine/srbščine je novejši in ni tako močan, seveda pa se socialne zvrsti med seboj prepletajo, zato je predvsem pri mladih zani-

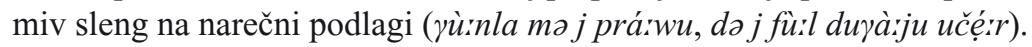

Kazalni zaimki in prislovi so podaljšani z -la (tá:la 'ta', yú:nla 'tisti', kó:la 'tako', 'tomla 'tam', 'səmla 'sem', yó:rla 'gor').

\subsection{Hišna imena}

Stara hišna imena tako kot ledinska kažejo na hišno in krajevno zgodovino. Domačije so navadno prevzele hišno ime po svojem ustanovitelju ali po njegovem poklicu, nekatera imena pa so se ohranjala skozi stoletja. Nekatera hišna imena izvirajo iz osebnih, ta pa iz svetniških imen: Luka > Ùkac, Jera > Jerí:̌̌ Štefan > Šté: fal, Tomaž > Tomá:žuc, Janez > 'Janšč, Á:nže.

Stvarna hišna imena v Topolah so Šú:ykar, Pí:pan, Špalá:j, Tastẹ:n, stanovsko Žní:dar (krojač), po živalih se hiše imenujejo par Kumá:rja, Záijc in Vov'kə, po rastlinah pa par Hrín. 


\subsection{Frazemi}

$\mathrm{V}$ topolskem govoru se pojavljajo marsikatere zanimive primere in prispodobe. Nekateri frazemi so značilni prav za Topole in bližnjo okolico. Vsi so zelo ekspresivni, vendar se ne omejujejo samo na neuradne ali nejavne govorne položaje.

Posameznikove fizične lastnosti opisujejo tile frazemi:

(imeti) rit ko od fapa blatnik (imeti) zelo veliko zadnjico: 'rət kə ut fá:pa bwá:tə⿹k (biti) širok ko metrga (biti) zelo debel: š'rok kə mẹ́:tərga

(biti) dolg ko lojtra (biti) zelo velik, po navadi tudi suh: doux kə 'wəi্রেa

švicati ko farovški hlapec potiti se brez fizičnega napora, navadno pri jedi: šví:caš kə fá:ruškə hwá:pəc ${ }^{18}$

(biti) tako kumrn, da s posteljo vred štirideset kil vaga (je) zelo, bolezensko suh: ko kú:mərən, da s pọ́:stlo vret š'tərdəsət 'kil vá:ya

(biti) pijan ko mavra (biti) zelo pijan: p'jən kə má:ưra

imeti kožico med prsti živeti v severnem delu vasi: mẹ́:t kọ́:šco mət pòrstam ${ }^{19}$

Posameznikove psihične, značajske lastnosti ali navade/razvade se skrivajo v naslednjih frazemih:

(biti) tako brihten, da mu škoduje $s$ svojim govorjenjem vzbujati slab vtis pri drugih: kọ́ brí:xtən, də 'mo škọ́:dje

(biti) len ko fuks (biti) zelo len: 'len kə 'fuks

(biti) neumen ko noč zelo neumen: naú:mən kə nọ́:č

(biti) smotan ko zajla $s$ svojim neprilagodljivim vedenjem vzbujati odpor, nenaklonjenost: smó:tan kə zá:jla

(biti) zabit ko štirna (biti) omejen, neumen: zəbì:t kə štẹ:rna

(biti) tečen/siten ko spodrepna muha (biti) zelo nadležen: tẹ́:čən, sí:tən kə spudrẹ́:pna mú:xa

(biti) težak ko cent (biti) težaven, naporen: tə'žək kə 'cent

(biti) na ta mrzlo nogo (biti) zelo nerazpoložen: dó:nəs jə pa ná:ša nə tə mə̀rzwo nưọ́: (wstá:wa)

jermen dol pasti (komu) izgubiti voljo do dela, delovno vnemo: a 'tep 'nep jé:rmon 'dol pá:du

pripravljati se ko ta usran za plotom zelo se obotavljati: se pərprá:ulla kə tə us'ran za plọ́:tam

goniti se ko stara štirna spolno se izživljati: gọ́n se kə stá:ra štẹ́:rna

pljuvati ko star čikež grdo pljuvati naokrog: plú:je kə s'tər čí:kəš

${ }_{18}$ Ta frazem ne nakazuje nujno, da nekdo malo dela: prepoti se že pri manj zahtevnih opravilih.

${ }^{19}$ Frazem je dokaj huda zbadljivka in pomeni tudi prebivalca sosednje vasi Suhadole, ki jim Topolci rečejo tudi »žabarji«. Med Topolami in Suhadolami so travniki in polja, ki so delno zamočvirjena, zato je tam veliko žab, saj struga Pšate v tem delu ni regulirana, ampak teče ob gozdu in ima mnogo ovinkov. Frazem lahko označuje tudi Topolca iz severnega dela vasi, ki meji na Suhadole, ali Topolca, ki prijateljuje s Suhadolci (zato naj bi bila kožica med prsti »nalezljiva«). Če žabe v času parjenja pridejo v vas (kar se sicer zgodi redko), se v vasi reče: $\mathrm{Na}$, spet so Skadóruç udd̀rla. 
- Veliko frazemov opisuje tudi premikanje:

[x leteti ko sneta sekira zelo hitro vozitilteči: lətì: kə snẹ́:ta skẹ́:ra

voziti, ko bi se (komu) sanjalo vozi zelo počasi, razmišljeno: vọ́:zəš kə dəp se tə saná:u hoditi ko megla počasi, brezvoljno hoditi: họ́:dəš kə məg'la

Frazemi govorjenja:

imeti jezik veliko, predrzno govoriti: lẹ́:j ja, k 'ma jé:zək

cviliti ko mlada miš govoriti/oglašati se z visokim, neprijetnim glasom: cvíllat kə mwá:da 'məš

kleti ko star furman veliko preklinjati: kó:une kə s'tər fú:rmən

Drugi frazemi:

(piti) ko bi cerkev prodali za pijačo (ali hrano, veseljačenje) zapraviti veliko denarja: pjé:jo, kə dəp cẹ́:rku pər'dal

dol gnati koga imeti prebavne težave, drisko: dó:nəs me pa že ceu dà:n dò:l žé:ne gledati v luft biti brez dela: $\gamma$ lẹ́: dat u 'ləft

govoriti (s kom) biti (s kom) v ljubezenskem razmerju: ted'va pa že 'dəl 'cajt

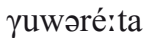

koga jesti prosi (koga) zakaj ne more ( $k$ do česa - ne pa tudi koga) pustiti pri miru: 'sam kưá: te tọ́:la jẹ́:st prọ́:s

biti prekmalu rojen narediti kaj narobe, predvsem v poklicu: za kəj tá:zүa mọ́:rəš bí:t pa 'tut prəxmá:u ró:jən

\section{$5 \quad$ Sociolingvistična opažanja}

Vpliv knjižnega jezika in drugih (ne le okoliških) govorov je dokaj močan, saj vsi vaščani obiskujejo šolo ali hodijo na delo v drug kraj, kar gotovo vpliva na njihov osebni govor. Prav tako zaradi majhne vasi poroke med vaščani niso pogoste. Zanimivo je, da se pri mlajših v narečju sporazumeva več fantov kot deklet, nekatera dekleta (verjetno zaradi prestiža, želje po potrditvi v družbi) narečje popolnoma opuščajo, kar se še posebej kaže pri švapanju, ki ga pri dekletih skoraj ne slišimo več. Manjši otroci so navadno govorci jezika starih staršev, saj še vedno precej otrok pred osnovno šolo ne hodi v vrtec, seveda pa jih doma ostaja manj kot pred leti. Javni govorni položaji vplivajo na izbor besedja, manj pa na izgovor glasov, posebej priporniškega zvenečega $\gamma$, ki se ga tudi mnogi šolani govorci nikoli ne znebijo povsem.

\section{Topolsko-knjižnoslovenski slovarček ${ }^{20}$}

bertah (tudi fertah) • bẹ́:rtax -a m predpasnik: kər u bertah se ubriš bij • 'baj medm. klic vpregi naprej!

bisteger $\bullet$ bìssteyər medm. klic vpregi na levo!

${ }^{20}$ Topolsko-slovenski slovarček sestavljajo poknjižena in narečna iztočnica, njena pomenska razlaga in ponazarjalni zgled $v$ poenostavljenem zapisu. Besedne vrste so označene 
bognedaj • bọ́:xnədej čl. bog ne daj |nikar|: A: sneh bo B: bohnədej že spet bogvedi • bọ́:xvet čl. bogve $\mid k d o$ ve|: A: kje je Janəz? B: bohvet bolji • ból -- -- prid., primernik od dó:bər boljši: v povedni rabi sej bo bol, boš vidu brihten • brí:htən -tna -tən prid. pameten, zvit: guna j prov brihtna cruk $\bullet$ crù:k medm. klic vpregi nazaj!

cviren • cvẹ̀:rən -rna m sukanec: a mə uhka cverən not udanəš? ček • čé:k -a m položnica: ta mesəc so me pa koštál čekə

dajati se $\bullet$ də’jət se dəjẹ̀:m se nedov. prepirati se, meriti se v čem: kuga se dej dəjeta? dedec $\triangleright$ dè:c $-\mathrm{a}$ m 1 dedec $\mid$ moški| $\mathbf{2}$ mož |zakonski|: dec mə j djav, də ga noun na južno dejati • djá:t nedov., samo kot deležnik na -1 (je djá:wa) reči: kuga s djaư ?

ega $\triangleright$ èrya medm. klic vpregi stoj!

encajt • əncà:jt prisl. nekaj časa: tola v əncajt traju

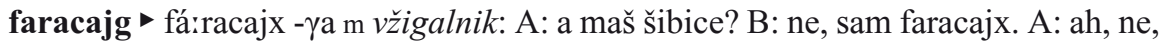
dya pa na nucam, tko retkəh zop pa še nimam

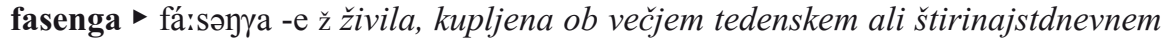
nakupu: sva šva pu fasəngo u štacuno

fertik - fé:rtik -- -- prid. 1 zelo utrujen, izčrpan: po temo deu səm pa čist fertik $\mathbf{2}$ v povedni rabi konec: sam da b bo že dya ankət fertik

firbčen • fẹ̀:rpčən -čna -čən prid. radoveden: po kermo s ti tko ferpčən?

firenk $\vee$ fẹ̀:rə⿹k -a m zavesa: a lohk ferənke na mer pəstiš?

firkeljc $\vee$ fẹ̀:rkəlc -a m četrt, četrtina: A: kok je ura? B: ferkəlc čəz 'əno

firtah (tudi birtah) $\bullet$ fẹ̀:rtax -a m predpasnik: dej sə no fertah pretse

fržol • fər'žou -ó:wa m fižol: a s fəržov že usadu?

fržolov • fržó:vu fržó:vuva fržó:vu prid. fižolov: u petkəh mamo zmer fržovuvo župo pa omlete

fuks • fù:ks -a m konj, navadno nekoliko oslabel • BITI LEN KO STAR FUKS čustv. zelo len: ta j pa len kə stər fuks

furati - fù:rat -am nedov. voziti (navadno brez upoštevanja prometnih predpisov): glej ga, kuko se pu vas fura

gamazin • yəmazí:n -a m prostor za hranjenje poljskih pridelkov, kašča: uso všenico mamo $v$ gəmazin

garkelj • yá:rkəl -na m ograjen vrt |za vrtnino, okrasne rastline|: pejt mə v garkəl pu pətəršil

gas • • (BITI) POD GASOM pud yà:sam poud. (biti) pijan: zmer je pud gasam vozu, k je biv pa ənkət trezən, so ga pa pulcajə ustavlə, da nima luči

gmah $\vee \gamma^{\prime}$ məx $\gamma$ má:xa m mir: dej mə gməh

gorko • yurkọ̀: prisl. toplo: tla j pa gurko gratu

v skladu z načeli v Slovarju slovenskega knjižnega jezika. Samostalniki so opremljeni s podatkom o spolu (m, ž, s), glagoli s podatkom o vidu, pridevniki s podatki o edninskih imenovalniških oblikah za vse tri spole. Ob osnovni so kot v SSKJ navedene druge slovarske oblike, ki jih v primeru izgovornih posebnosti lahko spremljajo še podatki o drugih oblikah Od nepregibnih besednih vrst so v slovarčku zastopani prislovi (prisl.), predlogi (predl.) in medmeti (medm.). Slovarček obsega samo nekatere besede, ki so bolj značilne za Topole in bližnjo okolico, čeprav so vanj uvrščene tudi nekatere besede, ki so splošno razširjene po celotnem slovenskem ozemlju. 


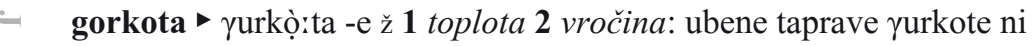
got $•$ ò:t medm. klic vpregi desno!

gratati • grá:tat tudi $\gamma$ rá:tat -am dov. posrečiti se, uspeti: potica to je pa gratuva • poud. GRATATI KAJ IZ KOGA razviti se, postati: puglej, kuga j gratu z nega!

gredenca - yrədè:nca -e tudi kredè:nca -e ž kuhinjska omara: dej ta bol talarje z grədence na mizo

gruntati $\vee \gamma$ rú:ntat -am nedov. misliti

gverati $\vee \gamma$ vẹ́:rat -am nedov. trajati

hlabec $・$ xvà:boc -pca $\mathrm{m}$ zdevalni stol |priprava, na kateri se stoji pri zlaganju česa v kozolec

ketnja • kẹ́:tna -e ž veriga: ketna mə j dol padva

kevder $•$ kẹ́:ưdər -dra m klet: grem u kevdər pu kəmper

koga $\triangleright$ kuүá: zaim. kaj: kuga b rəd?

koj • kù:j prisl. takoj: kuj prid dol

kole kó:la prisl. takole: kola naret, pa bo

kolikokat • kọ́:kat prisl. kolikokrat: kokat sə šu pu utroke?

kompnik • kó:mpəクk -a m zaprtek jjajce|: ah, tola j pa kompənk, nov nəč $\rightarrow$ kompovec

kompovec kó:mpuc -a m zaprtek |jajce $\rightarrow$ kompnik

kovter $\gg$ kó:untər -tra m prešita odeja: a čəš kovtər za spat?

kompir • kəmpẹ́:r -ja m krompir: narraj ma kəmper u žup

kredenca $\rightarrow$ gredenca

ksiht • ksì:xt -a m obraz • čustv. NAREDITI KSIHT spremeniti izraz na obrazu: lej, kašən ksiht je naredu

kunšten • kú:nštən -tna -tən prid. pameten, zvit: ta j pa ko kunštən, də mu kər škodje lahko • uhká prisl. lahko: a mə uhka pumagaš?

lagati • wa' $\gamma$ ət wá:žəm nedov. lagati: kuga važəš?

lamber • lá:mbər tudi wá:mbər -ja m vedro: kəm'ne pa v lambər puber • kuko pa ti misləš jabuka brez vambərja poberat?

lata • vá:ta -e ž lata $\mid v$ kozolcu|: na, spet sə j vata zvəmiva

lintvern • lí:ntvərən -rna m poud. nagajiv, nemiren otrok: kašən lintvərən je ta utrok lojtra $\vee$ 'wojtra -e ž lestev: vəjtro pərsvon, pa češne uber

$\operatorname{marod} \vee$ marọ̀:t -- -- prid. bolan: dons səm pa ko marot

marodirati • marodẹ̀:rat -am nedov. biti na bolniškem dopustu: veš, kok cajta že marodera?

mesteje • məstẹ̀:je -tẹ̀:j ž mn. votlina med odprtino krušne peči in dimnikom, v kateri sušijo meso

mevkica • mé:unkica -e ž regratova lučka: a uš pihu mevkice?

mustače $\triangleright$ mustá:če -tà: ̌̌ ž mn. brki: kašne mustače ma Janəs $\rightarrow$ smotače

nabasan • nabà:san -a -san prid. čustv. pijan: sam, kuko j nabasan pəršu dam

nacejati se • nacé:jat se -am se nedov. veliko piti |alkoholne pijače|: pol so se ga pa nacejal, kə də so cerku pərdal

nacukan - nacù:kan -a -kan prid. vinjen, okajen: zmer jə biv mav nacukan, tko da nis ənkol za gvišən vedu

naš • 'nəš ná:žła m mož |zakonski|: nəš je ko pridən, də preh z mize pusprav, predən pojedmo 
naša • ná:ša -e ž žena $\mid$ zakonska|: naša j pa ko natančna, de j kər prəveč nikamor • əクkà:mər prisl. nikamor: kuga se derəš, sej ənkamər na grem nikar ə⿹kà:r čl. nikar: dya pa ənkar ukroh na govor nikoli • ə⿹kò:1 prisl. nikoli: ne, jəs nisəm pa ənkol nəč svabga v šol naredu občina - ò:pčina -e ž urad: dons morəm pa še na opčino $\mathbf{K}$ vsi uradi, od občine do upravne enote

obrajtati • ubrá:jtat -am nedov. ceniti: nega pa zvə ubrajtajo na šiht ohrn • vọ̀:xərən -rna, -rən prid. skop: kuko j pa ta čvovk vohərən onegaviti • uyyá:ưt -á:vəm nedov. 1 kaj početi 2 truditi se brez uspeha

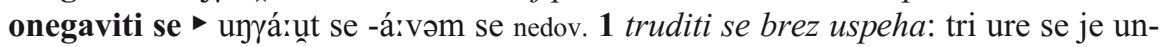
gavu z drvmi 2 spolno občevati: A: na vem, a se sam ungavta? - B: ja, kuga pa j pol? a s jəma fovš?

oreng • ọ́:rə⿹k prisl. popolnoma, čisto: nazadne je pa le orənk pupravu mašino osirati • osẹ́:rat -am nedov. obrekovati: kerga že spet oserate?

oster $\vee$ ujs'tər -t'ra -'tər prid. močen, oster

pajkelj • pá:jkəl -na m vejalnik|naprava za odstranjevanje plev in primesi pri žitu|: učas nis mogu bres, zdej jə pa pajkəl sam u napoto

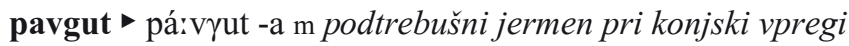

peglezen • pẹ̀: $\gamma$ ləzən -zna m likalnik: s pegleznam səm se uparva

penzelj • pẹ́:nzəl -zla m čopič: tola vš pa druh penzəl nucu

pir pẹ̀:r -a m pivo: a grəva na n per?

pisker p pí:skər -kra m 1 lonec 2 čustv. glava: piskər mə bo raznesvə

podložek • pudvọ̀:žək -ška m podložek |jajce|: čə greš pu jajca, merki, də navš pudvožka vzeva

poglobiti se • poyọ́:bat se -əm se dov. udreti se |led pod nogami|: pol se m je pa sam pogobu

pogruntati • poyrú:ntat -am nedov. izmisliti si, domisliti se: tola s pa dobər pogruntu

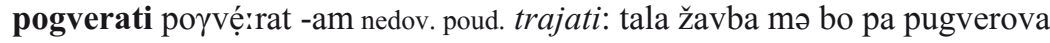
porajtati • porá:jtat -am dov. opaziti: sploh nisəm porajtu de j že noč pošter $\rightarrow$ povšter povšter pó:ưštər tudi pọ́:štər -tra m vzglavnik|blazina|: sej maš vəs zamazan povšter prec $\bullet$ p'rec prisl. takoj: prec pridəm

puščavnik • pəšàivəうk -a m osla |za brušenje kose|: kam s pəšavənk utaknu?

rokav ru'kau -á:wa m, mn. ruká:la -u rokav: oblec sə dovge rukala, kə te bo drgač zebvo

rukrem • rù:krem -ov m mn. vlečni bočni jermeni pri konjski vpregi

rutka • rú:tka -e ž okrasni robec: dərgač nəč na da nase, ampak rutko pa more met smotače $•$ smətá:če -tà:č ž mn. brki $\rightarrow$ mustače

stelja • stẹ́:wa tudi stẹ́:la -e ž stelja: steve nəm bo zmanku

streknjati • strək'nət -ám dov. potratiti: a maš še kej znamk a sə use strəknou?

svisli • svì̀sle svìsslu ž mn. (u svìssləx) prostor za shranjevanje slame: merki na vrata pər svisləh, kə se težko uhperajo

šaflja • šà:fla -e ž lopata z listom, ki ima navzgor zavihane stranske robove: še no šaflo mavte dej, po bo pa dost

šajtrga • šà:jtərya -e ž samokolnica: gnoj pa kər s šajtərgo v garkəl pərpel 
— Šalca • šà:lca -e ž skodelica: eno šalco kufeta mə dej

šantati • šən'tət -tà:m nedov. šepati: zakuga pa šantaš?

šarf • šà:rf -- -- prid. 1 oster |močnega okusa|: tala hrən je pa šarf $\mathbf{2}$ odrezav, oster: negova baba je pa šarf

šibica • šìibica -e ž vžigalica: a maš šibice?

šiht • šìxt -a m 1 služba $\mid$ delo|: ne, v petək mam pa šiht, na morəm 2 izmena

škrpet - škərpè:t -a m obrabljen, ponošen čevelj: a v təh škrpetəh misləš navkol letat?

šolen • šọ́:lən -lna m boljši (tudi plesni) nizki čevelj, pri ženskah navadno s peto: glej, da vš dava šolne za $h$ ta bolmo gvant

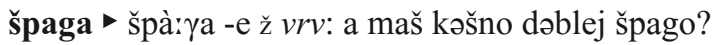

špegel • špè̀: $\gamma \mathrm{u}$ - $\gamma \mathrm{la}$ m ogledalo: čə se vš prədovh u špegu gledu, tə bojo uslovske ušesa zraslə

špegli • špè̀: $\gamma l ə-u$ m mn. očala: ni merkuva uči, dəj ma pa uhka špegle

špetir \špətẹ̀: $\mathrm{r}$-a m prepir: kašən špəter mata spet?

špetirovec • špətẹ̀:ruc -a m prepirljivec: ampak, sə pa nisəm mislu, de j tak špəteruc $-\mathrm{z}$ usem je skregan

šporget $•$ špò:ryet -a m štedilnik: a maš župo že na šporyet?

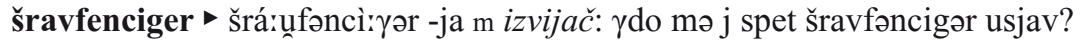

štacuna • štacú:na -e ž trgovina: a kej is štacune nucaš?

štala • štá:wa štá:le tudi štá:la -e ž hlev: u štal mamo pet glav žvine

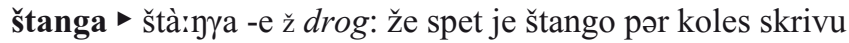

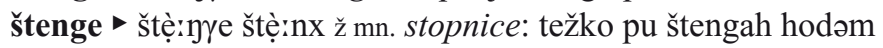

štrafati • štrà:fat -am dov./nedov. kaznovati: me j prec Boh štrafu

švoh • šlvox -- -- prid. šibek, slaboten: dons səm neki švoh

ta bol gvant • ta bọ̀:l $\gamma^{\prime}$ vənt ta bọ̀:l gvá:nta m praznična, boljša obleka |za k maši in za slovesnosti|: kva pa j donəs, de $\mathrm{j}$ u ta bolmo gvənt?

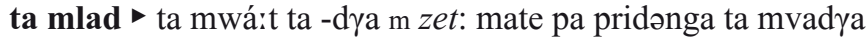

ta mlada • ta mwá:da ta -e ž snaha: kuga vaša ta mvada deva?

tacajt ko • tacà:jt kə vez. medtem ko: tacajt kə v luft gledaš, bə uhka kəmper nalupu talar • tá:lar -ja m krožnik: pujej, kər maš na talarjə

tenek - tə'nək -nka prid., v povedni rabi zelo občutljiv in zamerljiv: ənkar na bot ko tənək

tlake $・$ tlá:ke prisl. tukaj: tlake me pučaki

tošelj • tó:šəl -na m moška denarnica: tošl səm u varžət puzabu

traknati • trək'nət -am nedov. tratiti |predvsem denar|: ceu žiunlene jə biu navajən trəknət, dej more pa šparat

turen • tú:rən -rna m zvonik, stolp |tudi gasilski|: a so cəvi že pušəšene v turnə?

uleči • samo 3.os. ed ulẹ́:če nedov. pihati |veter|: matər, kuko vleče.

urajmati se - urà:jmat se -am se dov., nav. 3. os. zgoditi se, pripetiti se: urajma se tə, da se to təč na gvalo userje, utroka se pa nardi

uštimati (se) • uští:mat (se) -am (se) dov. urediti (se): kam pa greš, kə sə se tko uštimava?

vajeti • vá:jet vá:jet ž mn. vajeti |na uzdo pritrjen jermen za vodenje konja|

vamber $\rightarrow$ lamber

varžet • vá:ržət -a m žep: a maš kəšən robəc u varžət? 
večji • vẹ̀:č -- -- prid. 1 večji: ư⿱šenica j pa več k wan, 2 s kaz. zaim. najstarejšsi: kok je stər toj ta več?

velnica • vẹ̀:vənca -e ž velnica |naprava za zajemanje moke ali žita|: dej mə vevənco pərnes iz kuhne

vkup • w'kəp prisl. skupaj: pa smo le vsə vkəp pəršlə

zavolj tega - zaval d'ya prisl. zato: zaval dya to pa na morəm pumagat

zelo $\triangleright$ z'və prisl. zelo: a se tə zvə mədi?

zmerom • zmẹ̀:ram prisl. vedno, zmeraj: zmeram uhka pridəš

žavba • žà:ứba -e ž krema, mazilo • BITI Z VSEMI ŽAVBAMI NAMAZAN zvit, prebrisan:

Jerni j pa z usəm žaúbam namazan

žiher \̌í:xər prisl. lahko: v povedni rabi a grem žihər vən?

žleht • žlè:xt -- -- prid. 1 zloben: no, onkar ko žleht na bot 2 poreden, neubogljiv

župa • žú:pa -e žjuha: a mate vi zmeram župo pər južnə?

\section{$7 \quad$ Literatura}

Bezlaj 2005 = France Bezlaj, Etimološki slovar slovenskega jezika 4: Š-Ž, Ljubljana: SAZU - ZRC SAZU (izd.) - Založba ZRC (zal.), 2005.

Jagodic 1958 = Marija Jagodic, Narodopisna podoba Mengša in okolice, Mengeš: Svet za prosveto in kulturo ObLO, 1958.

Jemec 2000 = Mateja Jemec, Topole že več kot 750 let, Mengšan 7 (2000), št. 75, 28-30.

Jemec Tomazin 2008 = Mateja Jemec Tomazin, Topole nekdaj in danes: ob 60-letnici Prostovoljnega gasilskega društva Topole, Topole: Prostovoljno gasilsko društvo, 2008.

KLS 1971 = Krajevni leksikon Slovenije 2, Ljubljana: Državna založba Slovenije, 1971.

Logar 1993 = Tine Logar, Slovenska narečja, Ljubljana: Mladinska knjiga, 1993 (Cicero).

Logar 1996 = Tine Logar, Dialektološke in jezikovnozgodovinske razprave, ur. Karmen Kenda-Jež, Ljubljana: ZRC SAZU, 1996.

Logar - Rigler 1993 = Tine Logar - Jakob Rigler, Karta slovenskih narečij, Ljubljana: Geodetski zavod Slovenije, 1993.

Ramovš 1995 = Fran Ramovš, Kratka zgodovina slovenskega jezika 1, Ljubljana: ZRC SAZU (Zbirka ZRC 9).

Snoj 1997 = Marko Snoj, Slovenski etimološki slovar, Ljubljana: Mladinska knjiga, 1997.

Snoj 2009 = Marko Snoj, Etimološki slovar slovenskih zemljepisnih imen, Ljubljana: Modrijan - Založba ZRC, 2009.

Stražar 1980 = Stane Stražar, Na pomoč: Razvoj gasilstva v Občini Domžale, Domžale: Samoupravna interesna skupnost za varstvo pred požarom, 1980.

Stražar 1993 = Stane Stražar, Mengeš in Trzin skozi čas, Mengeš - Trzin: Krajevna skupnost, 1993.

Škofic 2001 = Jožica Škofic, Govorica jih izdaja, Kropa: Tomco, 2001. 


\section{The subdialect of the village of Topole (Slovenia)}

\section{Summary}

This article describes the subdialect of the village of Topole at various levels. It has the phonological and morphological characteristics of a typical Upper Carniolan dialect of Slovenian. Some of the characteristics described only became established in the last few years; a comparison was made using an article by Tine Logar describing the Mengeš subdialect, which he prepared in 1954. Although Topole is part of the municipality and parish of Mengeš and would therefore presumably have a greater similarity to the Mengeš subdialect, certain characteristics such as vowel reduction and substitution of $/ \mathrm{v} /$ for $/ 1 /$ in morphophonemic alternation are much more similar to forms used in neighboring Suhadole; for example, šú 'gone' (cf. standard Sln. šel), paršu 'come' (cf. prišel), swárbi 'would go' (cf. šla bi), and žá:wast 'sorrow' (cf. žalost). The article also presents widespread phrasemes used in everyday speech, some of which are only characteristic of (and intelligible to) the Topole subdialect (e.g., imeti kožico med prsti 'to have webbed fingers/toes').

The extent to which dialect features are found in locals' speech is especially shown in the use of dialect-based slang, whereby foreign-language slang elements are also expressed in dialect phonology. Although the Topole subdialect is losing some of its special features because of the modern lifestyle (with people being educated and working elsewhere), it is nonetheless continually adapting and remains the first language choice for communication both locally and in the wider environment. The description of the subdialect if followed by a Topole dialect-standard Slovenian glossary. 